\title{
Air to Ground Rocket Dispersion Minimization
}

\author{
Slobodan Mandić ${ }^{1)}$ \\ Saša Živković ${ }^{1)}$ \\ Siniša Jovančić ${ }^{1)}$ \\ Bojan Pavković ${ }^{1)}$
}

\begin{abstract}
Dispersion of the impact points of the unguided rockets is a consequence of disturbances, such as thrust misalignments, rocket asymmety, manufactoring inacuracy, etc. Infuence of some disturbances are most significant in the initial phase of flight when the rocket leaves the launcher due to the small velocity. This influence is minimized by rotation of the rockets in the launcher tube which in practice is realized by the guide pin connected to the rocket and groove in the launcher tube or by canted nozzles. Also the rotation of the rocket in the launching tube and in flight can be realized by canted fins foled in the nozzle when the rocket is in the launcher tube. These fins are deployed when the rocket leaves the tube and creates rocket rotation in free flight. The rolling moments of the rocket in the launcher tube and during free flight are calculated by CFD simulation. The CFD simulation is also used for calculation of the fin hinge moment generated by exaust gases from rocket motor which is required for deployement of the fins when the rocket leaves the launcher tube. The roll rate required for minimization of the rocket dispersions and roll rate in the launcher tube for various cant angle of the fins are calculated by 6DOF numerical simulation. The results of simulation are used to select the best value of the fins cant angle
\end{abstract}

Key words: air-to-ground rocket, unguided rocket, rocket trajectory, dispersion, roll rate of the rocket, numerical computation, computational fluid dynamics.

\section{Nomenclature}

$C_{A}$

$C_{\tilde{N} \alpha}$

$C_{\tilde{m} \alpha}$

$C_{\ell p}$

$C_{\ell \delta}$

$D$

$D_{T}$

$L, \tilde{M}, \tilde{N}$

$F_{x_{f}}, F_{y_{f}}, F_{z_{f}}$

$M_{x_{f}}, M_{y_{f}}, M_{z_{f}}$

$M$

$p$

$p_{0}$

$R_{\text {CEPn }}$

$V_{0}$

$\tilde{x}, \tilde{y}, \tilde{z}$

$x_{f}, y_{f}, z_{f}$

$\Delta x_{c p}$
-Axial force coefficient

- Normal force coefficient derivative due to angle of attack

-Pitching moment coefficient derivative due to angle of attack

-Rolling moment coefficient derivative due to roll rate

-Rolling moment coefficient derivative due to fin deflection angle

- Rocket diameter

-Distance between the launcher and the plane normal to the line of sight

-Rolling, pitching and yawing moment

-Forces components acting on a hinge axis

axis

-Mach number

-Roll rate

-Initial roll rate

$-\mathrm{CEP}$ in the plane normal to the line of sight

-Initial velocity

-Aeroballistic coordinate axis system

-Fin coordinate axis system

-Static margin $\delta_{\ell}$

$\varepsilon_{C E P}$ - Angular value of CEP

\section{Introduction}

$\mathrm{D}$ ISPERSION of the impact points of the unguided rockets is a consequence of disturbances, such as manufacturing inaccuracies, thrust misalignments, rocket asymmetry, atmospheric condition, firing platform motion and aiming errors. Influence of some disturbances, such as thrust misalignments and asymmetric aerodynamic can be minimized by spinning of the rocket. Spinning of the rocket during the flight is realized by cant angle of the stabilizing fins. Still, influence of these disturbances is most dominant in the initial phase of flight when the rocket leaves the launcher. Influence of the disturbances in this phase of flight can be minimized by rotation of the rocket in the launcher tube $[1,2,3]$.

Rotation of the rocket in the launcher tube can be achieved by the groove in the inner side of the launcher tube which forces the rotation of the rocket. The level of the rocket rotation is dictated by cant angle of the groove. The general problem of this solution is the weight of the launcher related to the thickness of the launcher tube and the difficulty related to the manufacturing.

Morse analyzed the effects of wake unsteady flow and velocity gradients of the rotor wake free stream boundary on rocket trajectory [4]. The force and moments, both steady and unsteady, were destabilizing while the rocket is in the rotor wake. By reducing static directional stability, the flight should be more repeatable and experience much less perturbation.

\footnotetext{
1) Military Technical Institute (VTI), Ratka Resanovića 1, 11132 Belgrade, SERBIA

Correspondence to: Slobodan Mandić: e-mail: msmanda@mts.rs
} 
Most attention was recently paid to computational fluid dynamics (CFD) methods to simulate the missile launch procedure and missile exhaust plume [5].

Lee presented CFD models to simulate the missile launch from a canister in general or from a helicopter with the focus on the missile movement [6].

The purpose of the paper is to analyze the possibility to use the stabilizing fins for both the rotation of the rocket in free flight and rotation in the launcher tube by folding them in the divergent part of the nozzle and launcher tube. The rotation of the rocket in the launcher tube is generated by the fins exposed to the exhaust gas of the burning propellant in the divergent part of the nozzle and launcher tube. These fins are deployed immediately after the rockets leaves the launcher tube by the moment over hinge axis of the fins generated by the exhaust gas of the burning propellant.

\section{Aerodynamic characteristics of the rocket}

Basic dimensions of the air to ground rocket analyzed in the paper are given in Fig.1. The rolling moment of the rocket is obtained by cant angle of the fins $\delta_{\ell}$.

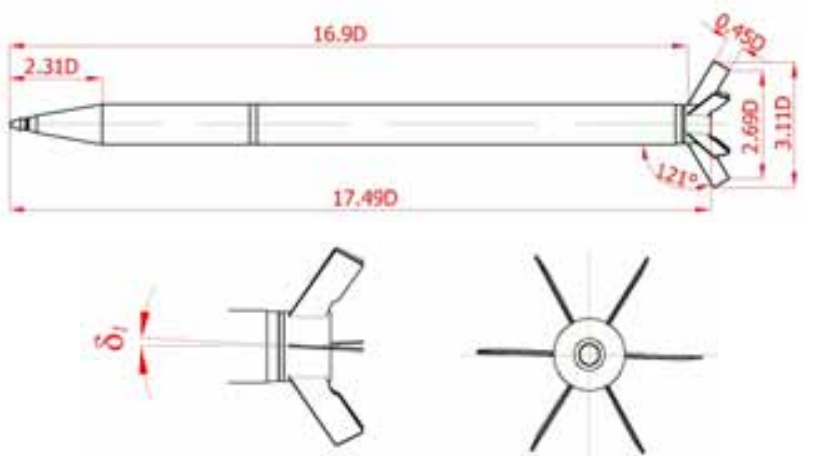

Figure 1. Basic dimensions of the model

Based on the basic dimensions of the rocket given in Fig.1, $3 \mathrm{D}$ model of the rocket is built (Fig.2).

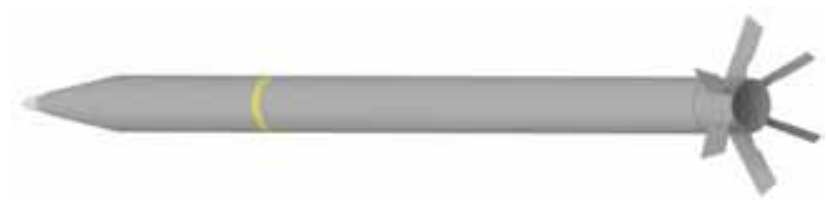

Figure 2. 3D model of the rocket

The aerodynamic characteristics of the rocket are determined by the semiempirical software DMAC [7] and by CFD calculation with FLUENT software [8]. Diagrams of the axial force coefficients are given in Fig.3. There are satisfactory agreement in the supersonic, while the difference in the subsonic region of Mach numbers is $20 \%$.

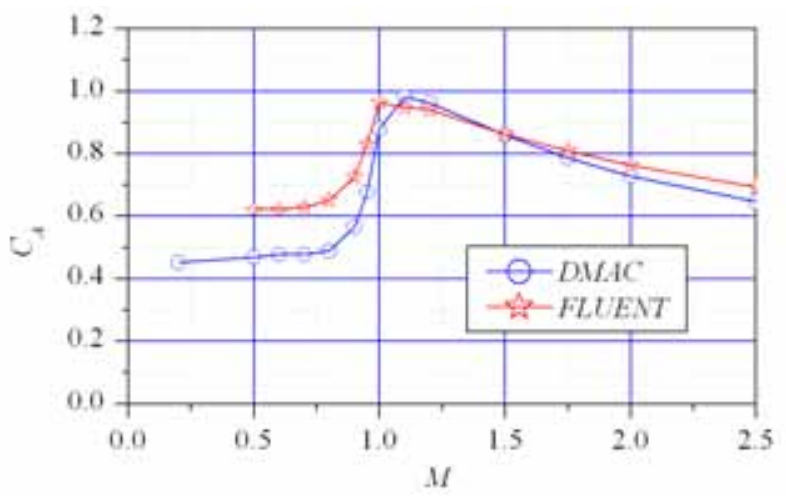

Figure 3. Axial force coefficients
Comparisons of the derivatives of the normal force obtained by semiepirical and CFD calculations are shown in Fig.4, while the comparisons of derivatives of pitching moment coefficients are given in Fig.5.

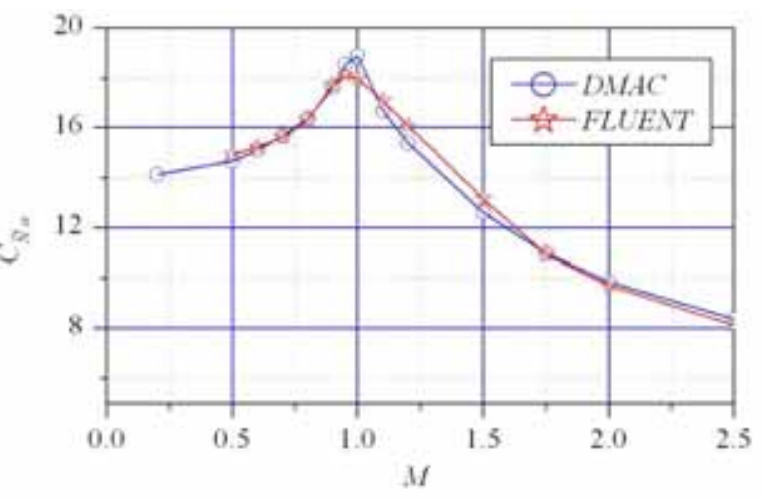

Figure 4. Derivative of normal force coefficients

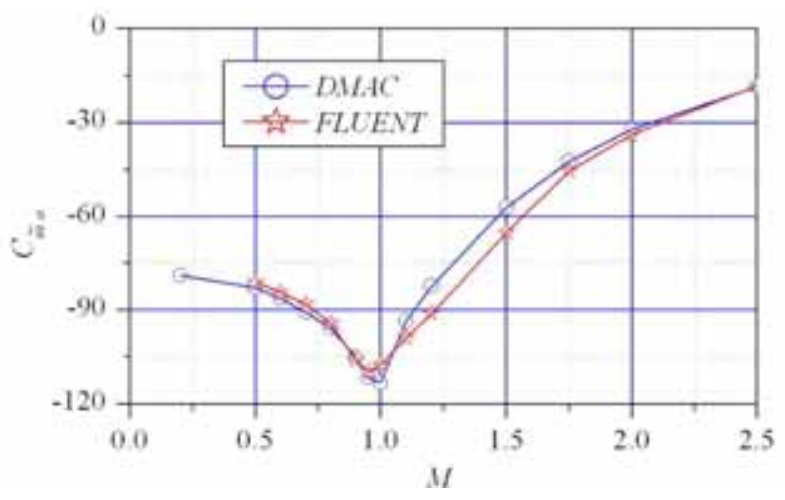

Figure 5. Derivative of pitching moment coefficients

Positive sign of the aerodynamic coefficients, forces and moments are illustrated in Fig.6.

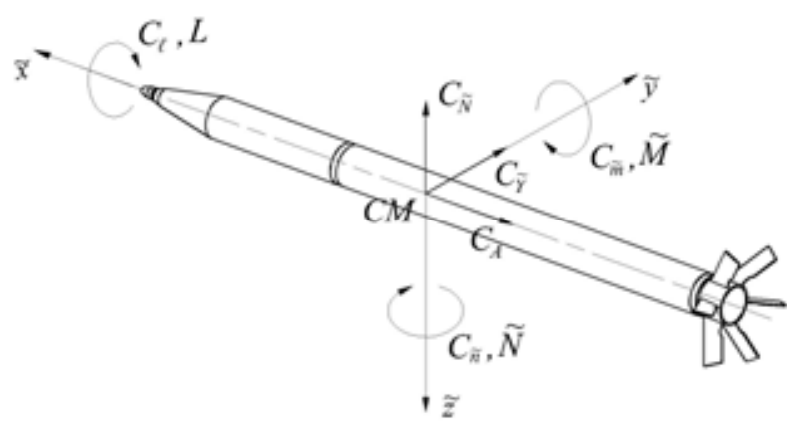

Figure 6. Aerodynamic forces and moments in aeroballistic axis system

\section{Dispersion of the air to ground rockets}

Since the trajectories of the air to ground rockets are almost straight line the sketch of the impact points on the plane normal to the line of sight are illustrated in Fig.7.

The circular probable errors (CEP) are not convinient for analysis of the dispersion of the air to ground rockets because CEP depends on distance between the launcher and the plane normal to the line of sight $\left(D_{T}\right)$. The angular value of CEP $\left(\varepsilon_{C E P}\right)$ is more convinient for analysis because this angular value of CEP is invariant to distance $D_{T}$.

$$
\varepsilon_{C E P}=\frac{R_{C E P n}}{D_{T}}
$$


where $R_{C E P n}$ is CEP in the plane normal to the line of sight.

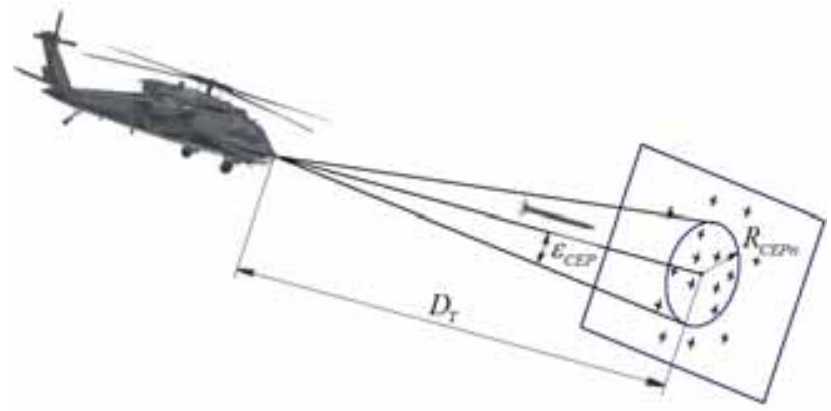

Figure 7. Sketch of the rocket impact points

Impact point dispersions of the air to ground rockets due to rocket parameters are analyzed by numerical simulation rockets trajectories in free flight by six degree of freedom (6DOF) simulation [9].

Influence of the cant angle of the stabilizing fins $\delta_{\ell}$ and static margin $\Delta x_{c p} / D$ to the angular dispersion $\varepsilon_{C E P}$ is given in Fig.8. There is a decrease of the angular dispersion with an increase of the cant angle of the stabilizing fins $\delta_{\ell}$ and increase of the static margin $\Delta x_{c p} / D$.

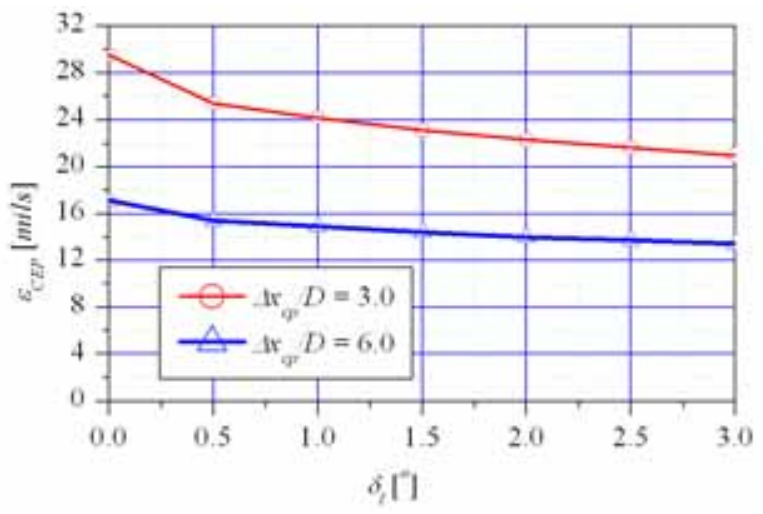

Figure 8. Dispersion due to cant angle of the fins

Influence of the initial velocity to the decrease of dispersion of the air to ground rockets is given in Fig.9. Increasing the initial velocity from $V_{0}=0 \mathrm{~m} / \mathrm{s}$ to $V_{0}=200 \mathrm{~m} / \mathrm{s}$, dispersions of the air to ground rockets decrease from $\varepsilon_{C E P}=29.5$ mils to $\varepsilon_{C E P}=6.1 \mathrm{mils}$.

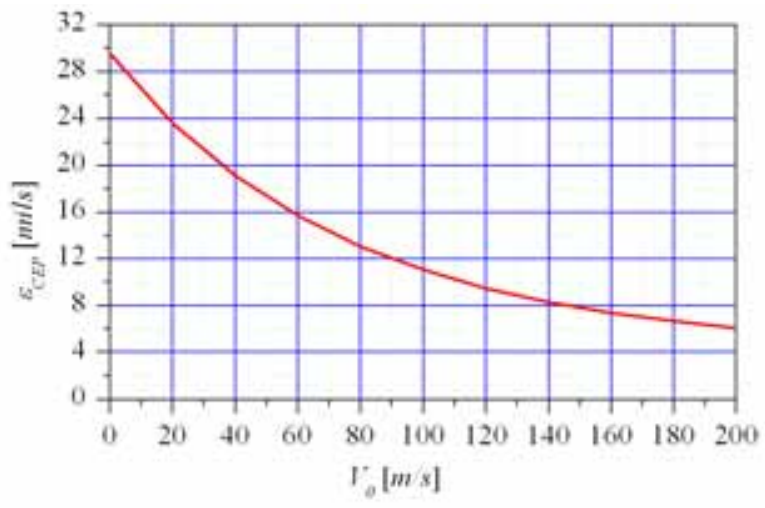

Figure 9. Dispersion of the air to ground rockets

Dispersion of the unguided rockets can be decreased also by rotation of the rockets in the launcher tube. Increasing the initial rotation of the rockets from $p_{0}=0 \mathrm{rad} / \mathrm{s}$ to $p_{0}=60 \mathrm{rad} / \mathrm{s}$ for zero initial velocity and cant angle of the fins $\delta_{\ell}=2.0^{\circ}$, dispersions of the air to ground rockets decrease from $\varepsilon_{C E P}=22.3$ mils to $\varepsilon_{C E P}=6.5$ mils (Fig.10).

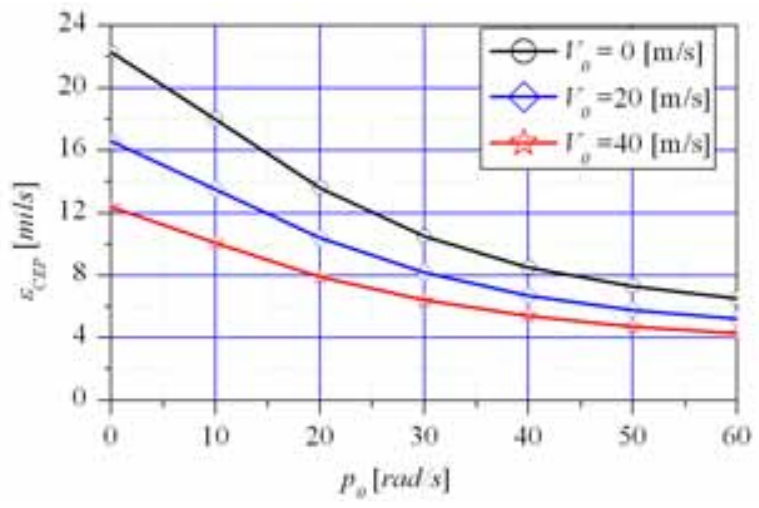

Figure 10. Dispersion of the air to ground rockets

Dispersion of the impact points of the air to ground rockets can be minimized by increase the roll rate of the rockets during the free flight in the atmosphere, the initial velocity and the initial roll rate of the rockets at the moment when the rocket leaves the launcher.

\section{Rocket rotation in the launcher tube}

The picture of the rear part of rocket 3D model with folded fins inside the divergent part of the rocket motor nozzle is presented in Fig.11.

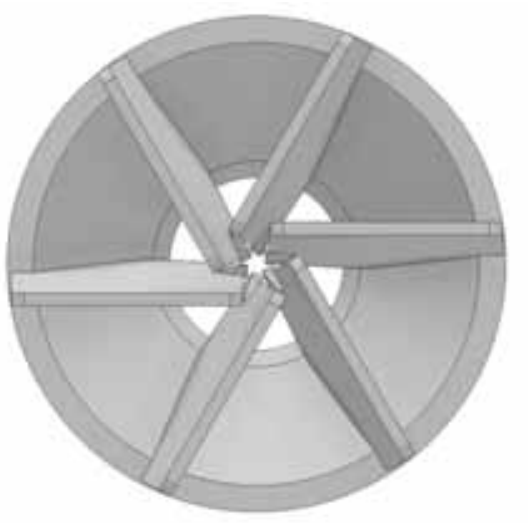

Figure 11. Rear part of the rocket 3D model

Computational domain is defined by inner surface of the nozzle, inner surface of the launcher tube from the nozzle to the end of the tube and surfaces of the folded fins inside the nozzle and launcher tube. An unstructured mesh composed of 10.409 millions of tetrahedral elements was generated in the computational domain with GAMBIT software package.

Cut dispay of the mesh of the nozzle, launcher tube and six fins inside divergent part of the nozzle and launcher tube is given in Fig.12.

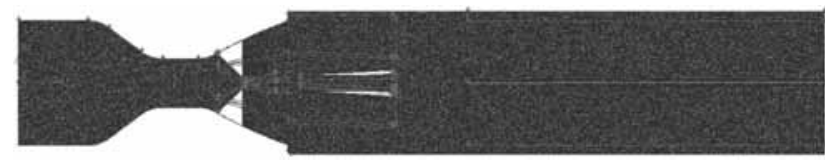

Figure 12. Cut display of the nozzle and launcher tube

Surface mesh of the two opposite fins exposed to the propellant combustion products flow in the divergent part of the nozzle and launcher tube is given in Fig.13. 


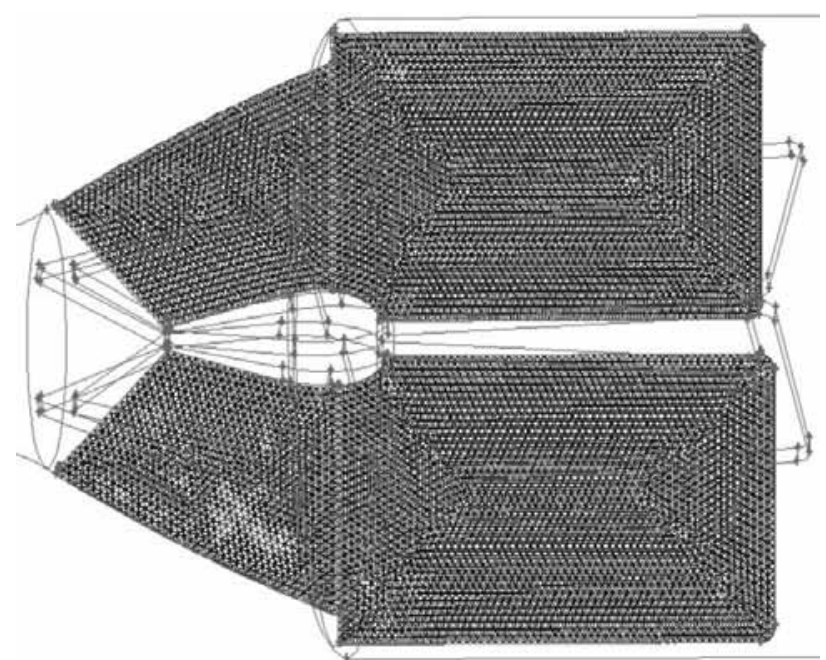

Figure 13. Surface mesh of the two opposite fins

Simulation of the exhaust gas flow of the burning propellant in the nozzle and launcher tube with folded fins was done by FLUENT software package [8]. The 3D density based second order explicit solver with $\mathrm{k}-\varepsilon$ realizable viscous model was used for numerical calculation of the flow in computational domain.

Working fluid is modeled as an ideal gas with parameters calculated for frozen expansion of propellants combustion products: specific heat $1770 \mathrm{~J} /(\mathrm{kg} \mathrm{K})$, thermal conductivity $0.2 \mathrm{~W} /(\mathrm{m} \mathrm{K})$, viscosity $7.7 \cdot 10^{-5} \mathrm{~kg} /(\mathrm{m} \mathrm{s})$ and molecular weight $23 \mathrm{~kg} / \mathrm{kmol}$.

Inlet of the nozzle was set as the mass-flow inlet boundary of the domain with next parameters: mass flow rate $5.3 \mathrm{~kg} / \mathrm{s}$; turbulent intensity $2 \%$, turbulent viscosity ratio 5 , and total temperature $2300 \mathrm{~K}$. Outlet of the launching tube was set as the pressure outlet boundary with sea-level conditions: total temperature $300 \mathrm{~K}$, pressure $101325 \mathrm{~Pa}$ and default turbulence parameters. All solid surfaces were set as no-slip, adiabatic wall boundary conditions.

Convergence of the numerical calculation of the flow was determined by tracking the change of the residuals. The numerical calculation of the forces and moments on the fins exposed the flow of the burning propellant was stopped when the forces and moments were changed less than $1 \%$ through 50 previous iterations.

Dislpay of the vertical cut of the dynamic pressure field in the control volume and dynamic pressure on the fins in front of the cut is given in Fig.14.
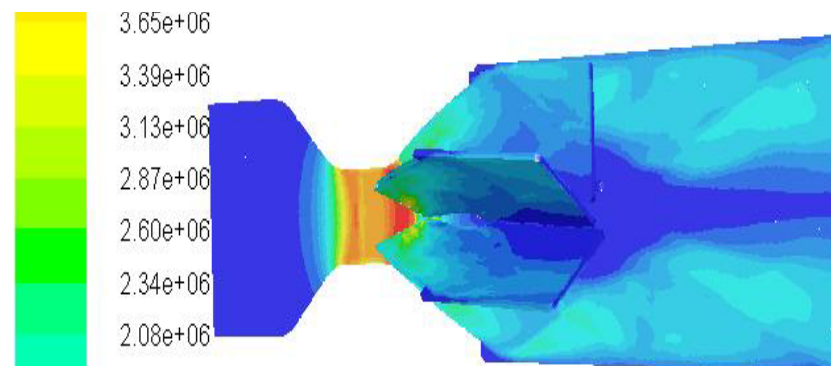

Figure 14. Dynamic pressure distribution inside the control volume, in $\mathrm{Pa}$

Dynamic pressure distribution on the inner surface of the nozzle and the part of the fins exposed to the exhaust gas of the burning propellant are given in Fig. 15.

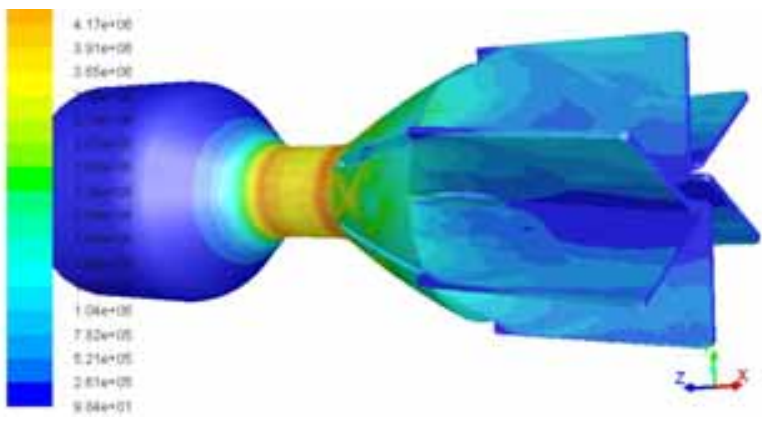

Figure 15. Dynamic pressure on the inner surface of the nozzle and fins, in $\mathrm{Pa}$

The calculated component of the forces and moments for the one fin in the axis system fixed to the hinge axis (Fig.16) are given in Table 1.

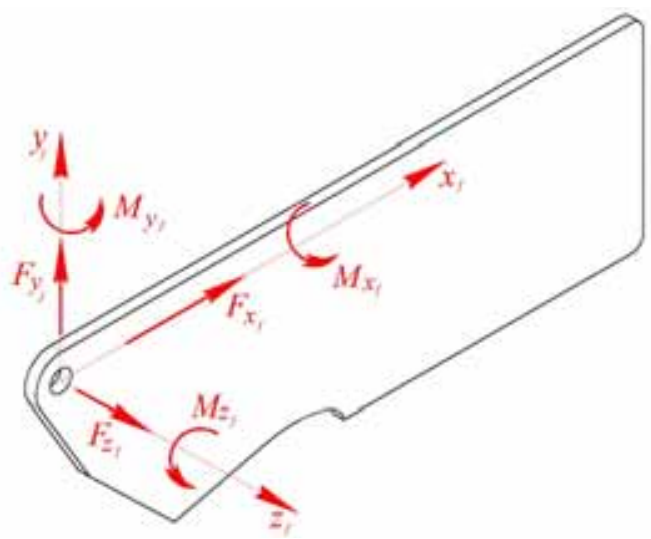

Figure 16. Forces and moments on the fins

Table 1. Forces and moments on the fins

\begin{tabular}{||c|c|c|c||}
\hline \hline Axis & $x_{f}$ & $y_{f}$ & $z_{f}$ \\
\hline \hline$F[N]$ & 438.0 & 382.0 & -97.0 \\
\hline$M[N m]$ & -0.27 & 7.0 & 12.9 \\
\hline
\end{tabular}

The positive sign of the calculated rolling moment of the rocket generated by six fins folded in the nozzle $L=21.5 \mathrm{Nm}$ is illustrated in Fig.6.

\section{Numerical simulation}

Aerodynamic derivatives of the rolling moment coefficient in function of Mach number are given in Fig. 17.

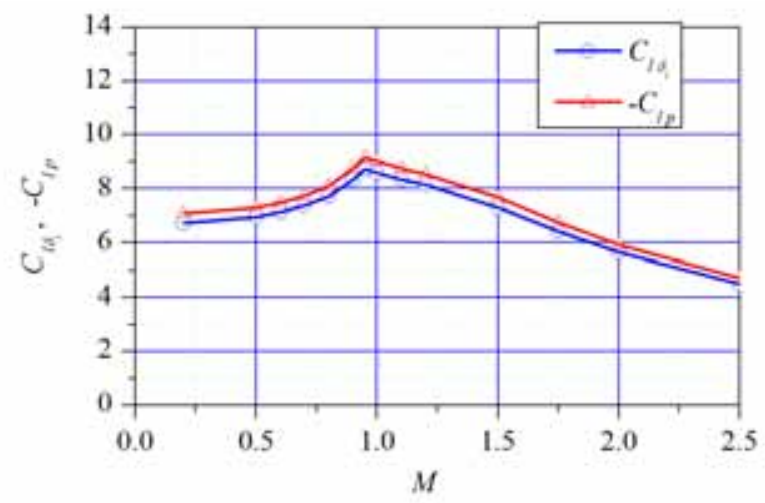

Figure 17. Aerodynamic derivatives of the rolling moment coefficients

Six degree of freedom software for trajectory calculation of the unguided rockets is used for calculation of the roll rate of the rocket in the launcher tube and during free flight after the rocket leaves the launcher tube [9]. 
Roll rates of the rocket in function of time of flight are given in Fig. 18 for three value of the cant angle of the fins $\left(\delta_{\ell}=1^{\circ}, \delta_{\ell}=2^{\circ}\right.$ and $\left.\delta_{\ell}=3^{\circ}\right)$.

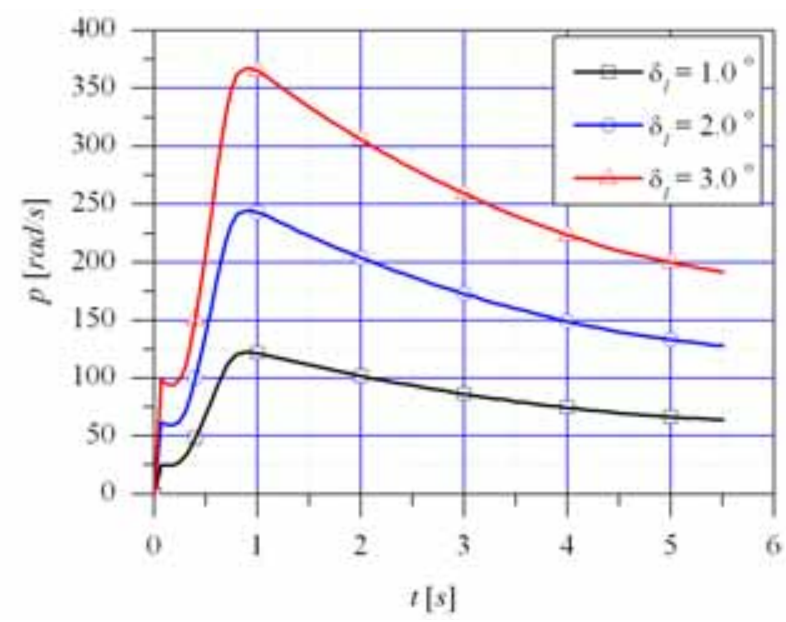

Figure 18. Roll rate of the rocket during free flight

The roll rates of the rocket in the launcher tube and vicinity of the launcher tube are illustrated in Fig.19.

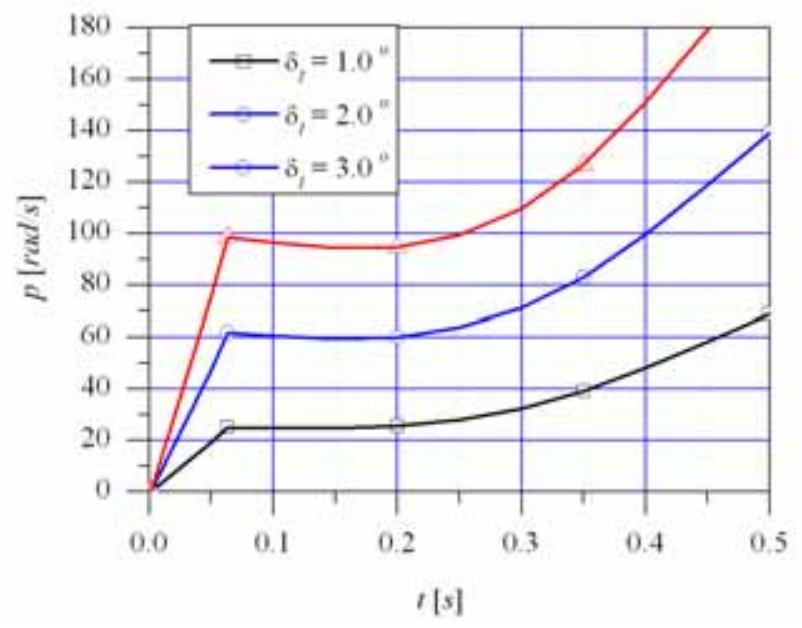

Figure 19. Roll rate of the rocket in the launcher tube

Having in mind the decrease of the dispersion with increase of the roll rate of the rocket at the muzzle of the launcher tube (Fig.10) and achieved roll rate with different cant angle (Fig.19), it can be concluded that satisfactory roll rate of the rocket in the launcher tube can be achieved with cant angle of the fins $\delta_{\ell}=2^{\circ}$.

\section{Conclusion}

Numerical simulations by 6DOF software are used for analysis of the rocket impact point dispersions due to rocket rotation during free flight, initial velocity, and rocket rotation in the launcher tube.
Since the initial velocity of the air to ground rockets launched from hovering helicopter is zero, the impact point dispersions can decraese by an increase of the rocket rotation in the launcher tube.

Influence of the manufacturing inaccuracies to rocket dispersion can be minimized by rotation of the rocket during the free flight in the air. This rotation can be generated by the cant angle of the fins.

The same fins folded in the divergent part of the nozzle can be used to generate the rotation of the rocket in the launcher tube.

CFD calculations are used to determine the forces and moments on the fins exposed to the exhaust gas of the burning propellant during movement of the rocket in the launcher tube. The forces and moments acting on the each fin are given in the axis system aligned with hinge axis of the fin. The most dominant moment is over fin hinge axis in the direction to open the fins.

The forces generated on the fins by the exhaust gas of the burning propellant create the rolling moment and rotation of the rocket in the launcher tube.

Six degree of freedom software for trajectory calculation of the unguided rockets is used for calculation of the roll rate of the rocket in the launcher tube and during free flight after the rocket leaves the launcher tube.

The roll rate required for minimization of the rocket dispersions and calculated roll rate for various cant angles of the fins are used to select the best value of the fins cant angle.

\section{References}

[1] GANTMAHER,F.R, LEVIN,L.M.: Teorija paljota neupravljemih raket, Fizmatgiz, Moskva, 1959.

[2] ЛЕБЕДЕВ,А.А., ЧЕРНОБРОВКИН,Л.С.: Динамика полета беспилотних летателних аппаратов, Машиностроение, Москва 1973.

[3] Design of aerodynamically stabilized free rockets - Military Handbook MIL-HDBK-762 (MI), 17. July 1990.

[4] MORSE,H.A.: Some Practical Aspects of Rotor Wake Effects on Rocket Accuracy, Technical Conference on the Effects of Helicopter Downwash on Free Projectiles, St. Louis, Missouri, SAD, 12-14. August 1975.

[5] LIU,N.S.: On the comprehensive modeling and simulation of combustion systems, Proceedings of the 39th AIAA Aerospace Sciences Meeting, Reno, New, USA, January 2001.

[6] LEE,B.S., CHOI,J.H., KWON,O.J.: Numerical simulation of free-flight rockets air-launched from helicopter, Journal of Aircraft, 2011, Vol.39, No.12, pp.1097-1106.

[7] ĆURČIN,M., STOJKOVIĆ,S., MILOŠEVIĆ,M.: DMAC-Derivatives Missile Aerodynamic Coefficients, VTI, Beograd, 1990.

[8] Ansys, Inc. FLUENT 6 and GAMBIT 2, licensed to VTI, Beograd.

[9] ĆURČIN,M., MANDIĆ,S., MILOŠEVIĆ,M.: UTC - Unguided Trajectory Calculation: $6 D O F$ trajectory calculation of the rockets and projectile, VTI, Belgrade, 2001.

\section{Smanjenje rasturanja pogodaka raketa vazduh zemlja}


pomoću CFD simulacije. Takođe, CFD simulacija korišćena je za proračun šarnirnog momenta stabilizatora koji su formirali izlazni gasovi raketnog motora, $i$ koji je potreban za otvaranje stabilizatora nakon izlaska iz lansirne cevi. Pomoću 6DOF numeričke simulacije izračunata je potrebna ugaona brzina za minimizaciju rasturanja rakete i potrebna ugaona brzina u lansirnoj cevi za različite vrednosti uglova nagiba stabilizatora u odnosu na uzdužu osu. Rezultati simulacije iskorišćeni su za odabir najpovoljnije vrednosti ugla nagiba sa aspekta minimalnog rasturanja.

Ključne reči: raketa vazduh-zemlja, nevođena raketa, putanja rakete, rasturanje pogodaka, ugaona brzina, numerička simulacija, numerička dinamika fluida.

\section{Minimisation de la dispersion chez les fusées air sol}

La dispersion des points de l'impact de la fusée non guidée est la conséquence des perturbations telles que l'excentricité de la force de poussée, l'assymétrie de fusée, l'imperfection de fabrication etc.L'influence de certaines perturbations est la plus signifiante dans la phase initiale du vol lorsque la fusée quitte le lanceur à la vitesse relativement petite. Cette influence se minimise avec la rotation de la fusée dans le tube de lancement qui est réalisée en pratique par le contact de la goupille de guidage de fusée et la rainure dans le tube ou au moyen des gicleurs inclinés. La rotation de fusée dans le tube se réalise aussi dans le vol par les stabilisateurs inclinés qui sont fermés dans le gisleur lorsque la fusée est dans le tube de lancement. Les stabilisateurs s'ouvrent quand la fusée quitte le tube de lancement et produisent la rotation de fusée en vol. Le mouvement du roulement de fusée dans le tube de lancement et pendant le vol libre a été calculé par la simulation CFD. Cette simulation a été utilisée aussi pour le calcul du moment des gonds de stabilisateur formé par les gaz d'échappement du moteur de fusée et qui est nécessaire pour l'ouverture des stabilisateurs après la sortie du tube de lancement. Par la simulation numérique 6DOF on a calculé la vitesse d'angle nécessaire pour la minimisation de la dispersion de fusée et la vitesse d'angle indispensable dans le tube de lancement pour les différentes valeurs des angles d'inclinaison des stabilisateurs par rapport à l'axe longitudinal. Les résultats de la simulation ont été employés pour choisir les meilleures valeurs de l'angle d'inclinaison sous l'aspect de la dispersion minimale.

Mots clés: fusée air sol, fusée non guidée, trajectoire de fusée, dispersion, vitesse d'angle, simulation numérique, dynamique mécanique des fluides.

\section{Сокращение рассеяния ударов ракет воздух-земля}

Рассеяние точек падения неуправляемой ракеты является следствием таких нарушений, как эксцентриситет тяги, асимметрия ракеты, несовершенство изготовления и т. д. Влияние определённых нарушений наиболее существенно в начальной фазе полёта, когда ракета покидает пусковую установку с относительно низкой скоростью. Этот эффект уменьшается за счёт вращения ракеты в пусковой трубе, что реализуется на практике путём контакта булавки ракеты и канавки в трубе или с помощью щелевых сопел. Кроме того, вращение ракеты в трубе и в полёте может быть достигнуто с помощью наклонных стабилизаторов, которые связаны в сопле, когда ракета находится в пусковой трубе. Стабилизаторы открываются, когда ракета покидает пусковую трубу и создают вращение ракеты в полёте. Момент катания ракеты в пусковой трубе и во время свободного полёта рассчитывался с помощью CFDмоделирования. Кроме того, CFD-моделирование использовалось для расчёта крутящего момента стабилизатора, который образовывали газы на выходе из ракетного двигателя, и который требуется, чтобы открыть стабилизатор после выхода из пусковой трубы. При численном 6DOF-моделировании требуемая угловая скорость рассчитывается для минимизации дисперсии ракеты и требуемой угловой скорости в пусковой трубе для различных углов наклона стабилизатора относительно продольной оси. Результаты моделирования были использованы для выбора наиболее выгодного значения угла наклона с точки зрения минимального рассеяния.

Ключевые слова: ракета воздух-земля, неуправляемая ракета, траектория полёта ракеты, рассеяние ударов, угловая скорость, численное моделирование, численная динамика жидкости. 